\title{
THE ROLE OF ENTREPRENEURS AND COOPERATION COMPETITIVE TO ECONOMIC WELL-BEING AND DEVELOPMENT
}

\section{Maryam Mangantar}

Faculty of Economics and Business, Sam Ratulangi University

\author{
A R T I C LE I N F O
}

\author{
Keywords : Entrepreneurs, Cooperation, \\ Economics, Development
}

Kata Kunci : Kewirausahaan, Koperasi, Ekonomi, berkembang

Corresponding author : Maryam Mangantar marjam.mangantar@gmail.com
Abstrack: The role of the entrepreneur is needed because of being similarly define the success of development. Many more role that an entrepreneur where the entrepreneur plays a role in increasing the economic activities, promote the nation's economy, improving the standard of living, reduce unemployment, tackle social tensions, and promote trade in both scale local, national and international. Actually, the role of entrepreneurs in promote world development have been conducted since their business activities. Businesses vying improve competitiveness by leveraging its competitive advantages of each, so that the entrepreneur had a hand in improving the well-being of society and have contributed also in the development of the world economy in general.

This paper aims to examine theoretically about the role of entrepreneurship and cooperation- competitive to economic wellbeing and development, beginning with the understanding of entrepreneur, the role of entrepreneur in economic development, cooperation-competitive, entrepreneur and coopetition, entrepreneur and coopetition role in achieving social well-being and development. It is hoped that this paper can open the mind of thinking about coopetition and the role of entrepreneur in achieving the welfare of society

Abstrak : Tulisan ini bertujuan mengkaji secara teoritis tentang peran kewirausahaan dan cooperation competitive to economic wellbeing and development, yang diawali dengan pengertian entrepreneur, peran entrepreneur dalam economic development, cooperation-competitive, entrepreneur dan coopetation, Entrepreneur and coopetition role in achieving social well-being and Development.

Diharapkan tulisan ini dapat membuka wawasan berpikir tentang coopetation dan peran wirausaha dalam mencapai kesejahteraan masyarakat. 


\section{Background}

INTRODUCTION

In the post modern age, the development of the world so rapidly in almost all areas in human life. Globalization is forcing humans to compete quickly. Progress in science and technology help humans to solving the problems of life. A wide variety of products and services available and with the help of advances in technology, the internet access that can be easily used as a means of economic transactions, consumers can get adequate services.

Consumers can also enjoy the ease among others in terms of time savings, quality, diversity of products or service, the price to the current way of shopping is shifting away from the conventional way of shopping to the modern way. All the activities that appear in the downstream were actually initiated from an upstream process of a simple obsession which later gave birth to the idea of a so-called entrepreneur. J. Schumpeter (1934) emphasized the importance of the role of entrepreneurs in the economic activity of a country, so as to boost economic growth. Their thinking is that the entrepreneur who have a myriad of ideas to innovate in economic activity, not limited to whether the innovation introduced new goods, enhances the efficiency in producing goods, expanding the market of a product to the market a new, developing the raw material sources of new and making changes in the organization. The role of the entrepreneur is needed because of being similarly define the success of development.

Many more role that an entrepreneur where the entrepreneur plays a role in increasing the economic activities, promote the nation's economy, improving the standard of living, reduce unemployment, tackle social tensions, and promote trade in both scale local, national and international.

Actually, the role of entrepreneurs in promote world development have been conducted since their business activities. Businesses vying improve competitiveness by leveraging its competitive advantages of each, so that the entrepreneur had a hand in improving the well-being of society and have contributed also in the development of the world economy in general.

If we examine further the role of entrepreneur coupled with entrepreneurship soul experienced a significant acceleration in the last decade. A shift where business interests are no longer simply rely on a competitive advantage, but trying to find a breakthrough strategy to perform competitive cooperation or coopetition strategy.

This paper is a literature study supported by empirical evidence that explore the role of entrepreneur and coopetition strategy in the public well-being and development, especially in the field of economic development in a global perspective. Beginning with the notion and function of the entrepreneur, understanding coopetition, the reason why entrepreneurs should do coopetition strategies, and the benefits gained when entrepreneurs do coopetition and the role of entrepreneur and competitive cooperation for improvement of social well-being and economic development globally.

\section{Entrepreneur.}

\section{LITERATURE REVIEW}

Entrepreneur is derived from a French term around the 17th century Entreprendre can notes tried in business or starting a business or someone who organize and run the risk of a business or enterprise. Meanwhile, according to Zimmerer (2008) is the application of creativity and entrepreneurship to solve the problem and attempt to exploit the opportunities that people face every day. According to Dubrin (2008) entrepreneur is someone who set up and run an innovative business.

The Entrepreneur is a generator driving the national economy through employment creation. This situation, will contribute to enhancing the purchasing power of the people and state revenue. The higher the income of the state, the country's ability to finance sustainable development more secure.

The positive impact of socio-economically by the entrepreneur is to create jobs, improve the quality of life, improve income distribution, use and mobilize resources to improve national productivity, and improve the wellbeing of government through government programs, such as taxes and others. Entrepreneur is the person doing the activity is characterized by clever or talented to identify new products, determine how new production, preparing the operation for the procurement of new products, marketing, and arranging capital operations.

An entrepreneur is always advisable to have a mindset that is out of the ordinary people in general and generate creativity and new innovations. An entrepreneur always enthusiasm every day, always motivate yourself, and smile in all situations. Entrepreneurs will see problems as a challenge. There is no word for entrepreneur fails, there is only success or learning. An entrepreneur is always trying to establish good communication with everyone, 
enrich science with more watching and listening, as well as sensitive to opportunities. Entrepreneurs see everything in terms of positive, changing the word could not be able to, it's hard to be easy, impossible becomes possible. An entrepreneur thinks about the future of many, many people's lives, people's well-being, and how to help those in need. Thus, entrepreneurs are not going to waste time on things that are not productive.

\section{Entrepreneur Role in Economic Development.}

Entrepreneur is an innovator and driving force of development, in fact, an entrepreneur is an aggressive catalyst for accelerating economic growth. Entrepreneurs are individuals who have a certain control of the means of production and produce more than can be consumed or sold or exchanged in order to earn income (McClelland, 1961). Entrepreneur is a creator of wealth through innovation, job growth and economic center, and the distribution of wealth that relies on hard work and risk-taking. This means that entrepreneurship is closely associated with economic growth. Entrepreneurship is not something new in the economy. The term entrepreneurship has been done since at least 150 years ago, and the concept has been around since 200 years ago (Bygrave, 2004). Given that the presence of an entrepreneur is amount to pushing economic change, which promotes economic growth and development, influence the emergence of entrepreneurship. There are two types of economic factors such as incentives for market: new social needs can be pursued to be met by the entrepreneur with new ways and there is sufficient preparation for the capital, to finance companies and institutions, which directs capital to people who want to use it for business activities.

To a certain extent, the richness of the old, is a pre-condition for the new wealth, in countries experiencing a shortage of economic vitality, or do not have market opportunities, as well as the capital required to fund their activities entrepreneurs. Many countries today are experiencing a shortage of equity capital invite potential investors, in order to increase the influx of capital into their economies.

Leeson and Boettke (2009) concluded that even economists are less expensive and the level of entrepreneurship in developing countries tend to ignore and one in understanding the relationship of entrepreneurial activity with economic performance. In fact, investing in productive technology that is the core of entrepreneurial productivity will generate impressive levels of economic development. The role of entrepreneurship in economic development also due to the ability to provide creative power of social values and economic, namely in terms of creating employment, innovation and new creations to the production of goods or services that people need, social capital and improve equity.

\section{Cooperation Competitive (Coopetition).}

Coopetition is a strategy in which a business unit in cooperation with other business units which become competitors and are usually still in one industry or similar industry. Coopetition is a condition in which we have cooperation and competition at the same time. Coopetition encompasses, in a single backbone, traditionally the two countervailing forces of cooperation and competition that, in today's fast-changing scenarios, require more attention and a comprehensive analytical treatment (Gnyawali, He and Madhavan, 2006).

Traditionally, the relationship between the competitors based on competition (Bengtsson \& Kock, 1999). In the business world, many companies decided to take action not only competitive, but also rely on the cooperation with the other competitors. Research conducted by Brandenburger and Nalebuff (1996) also G. Dagnino and Padula G. (2002), states that the competitive and cooperative actions at the same time. According Gnyawali and Jin (2007) coopetition is, simultaneous cooperation and competition between companies. In the last decade become increasingly popular because of the theme of coopetition an inspiration in addressing the development of business (Gnyawali, He, and Madhavan, 2008; Chen, 2008; Luo 2007; Ketchen, Snow, and Hoover, 2004; Bengtsson and Kock 2000).

In the reality of business, coopetition allows multiple winners in the marketplace. Business is not just a war to be won, with a winner getting everything. A more fundamental goal is how to maximize return on investment owned. (Prasastyo,2010)

Several studies have historically demonstrated the relevance of exploring coopetition that mindset as well as through the identification of models that better explain the competitive strengths and collaborative (Bengtsson and Kock, 2000). The research concludes that more than fifty percent of collaborative relationships (strategic alliance) between companies in the same industry or among competitors (Harbison and Pekar, 1998). While Coy, (2006) suggest that new businesses should do what is called the activity "Sleeping with the Enemy" or learn to work 
with rivals to be very important. As SAP CEO, Henning Kagermann stated that coopetition strength will grow as products become more complex and as competition widens globally (Coy 2006).

Coopetition help improve the technology diversity and incorporate complementary sources from rival companies by developing new technologies and products (Quintana-García and Benavides- Velasco 2004). Coopetition is very important to innovation in knowledge-intensive industries, dynamic, and complex (Carayannis and Alexander 1999).

The importance of coopetition be greater in the context of Micro Small and Medium Enterprises (SMEs). As the battle of technology has intensified and the technology has become more complex, SMEs face various challenges such as the rising costs of $\mathrm{R} \& \mathrm{D}$, high risk and uncertainty in technology development, as well as the lack of resources to pursue innovative large-scale projects (Bar Nir and Smith 2002; Gomes-Casseres 1997). SMEs in the industry must collaborate with competitors so that they can create economies of scale, risk mitigation and leverage resources together (Morris, Kocak, and Özer 2007). Competitors are likely to face similar challenges and have the resources and capabilities that are directly relevant to each other because they have the same high market and equality of resources (Chen 1996). SMEs more effectively compete with the big players if they collaborate with others (competitors) to access, acquire, and use relevant resources held by one another. The tendency of SME is to engage in coopetition have positive relationship with financial performance (Levy, Loebbecke, and Powell 2003). Coopetition be important in the business world because it is a concept that appears with increasing high-technology practice in the sector, a basic understanding of coopetition and implications. Mariani and Kylänen (2013) explore the role of public-private partnerships in the context coopetitive from time to time. This study emphasizes how the shape, nature and intensity of public-private partnerships as a feature of temporal changes in different coopetition. Their research findings that cooperation and coopetition can be strengthened by the public sphere and the publicprivate relationships are crucial in order to strengthen the brand image of a tourism destination or an entire region and to attract more tourists.

Coopetition consists of three main dimensions, namely, mutual benefit, trust, and commitment. Research from Akdogan et al (2015) in 4 companies in Turkey which implement business strategies coopetition stated that the main criterion is most important in coopetition is trust, commitment and mutual benefit. In addition, there are sub-criteria such as responsibility, trusted by the competitor, did not seek unilateral advantage and be responsible in general, loyalty, strengthen its competitive position, to have additional resources, not to act at the expense of partners, the willingness of competitors, sharing resources, cooperation considering significant and competitors willingness to change, structural similarities, given the benefit of a competitor, the willingness to share information, and not abusing the knowledge.

\section{Entrepreneur and Coopetition}

In carrying out the business of an entrepreneur must have used a variety of strategies to win the market. Here is the empirical finding of companies using business strategies coopetition. In the ASEAN region, conducted a study cooperation in the field of Telecommunications coopetition between companies Sing Tel Singapore and the company Smart Communications of the Philippines (Ananta et al, 2012). As a small country, Singapore is a developed country, has all the basic necessities, high per capita level, performance-oriented, have the human capital and financial capital, technologically advanced business systems. On the other side of the Philippines is a country with a score of PDI (Power Distance) and MAS (Masculinity versus femininity) is higher, and a moderate score in educated human capital and financial capital. The essence of coopetition is to think win-win and win-lose. If SingTel and Smart led the effort to share infrastructure and standardization of payment, they will change Telecom game for the greater good. Singapore and the Philippines complement each other perfectly. What is a drawback for the country is surplus in another country.

Coordination between the two countries in various fields such as telecommunications will work positively for both countries. The findings stated shared infrastructure enables enterprises to exercise economies of scale and save their investment costs while avoiding duplication.

In African countries (Sub-Saharan) Aladag (2012) conducted research about the conceptualization of coopetition ability of small and medium enterprises in developing Economic Environment. This research are conducted in 25 SMEs (15 in Zambia and 10 in Kenya) addressing how these capabilities can be conceptualized coopetition; what the consequences are and how it can be applied to SMEs. The reasons for selecting these locations 
because many countries in Sub-Saharan region was dominated by the activities of SMEs are highly burdened with limited resources and institutional challenges that threaten the competitiveness and viability of them. Learning coopetition in SMEs located in Sub-Saharan Africa provides useful insights into how coopetition capability helps improve the competitive position of SMEs in challenging conditions. Respondents reported that cooperation with their competitors is beneficial for their company's business activities as a partnership that allows the cost of the company's stock, learn from their competitors and pool resources together to achieve the common good and individual objectives. However, respondents also expressed the challenges they face in their cooperative relationships with competitors that seek to work with our competitors even though it is something we can't do alone. This is because the competitors, especially larger ones, have control over most of the decisions. Relations with competitors are not balanced and most experienced delays in delivery of services on the part of competing partners. This study provides a significant contribution to the advancement of knowledge about the cooperation among companies in general and in particular coopetition, in some ways. The first shows the relevance of coopetition capabilities, the ability to manage cooperation with competitors, to the context of SMEs. Given the complexity and uncertainty that characterize contemporary relations of cooperation, coopetition capabilities allow SMEs to develop and manage effective relationships coopetitive with the right partners to create and take advantage of market opportunities to compete. Second, consistent with Schilke and Goerzen (2010) conceptualization of alliance management capabilities, demonstrated that the ability of coopetition is a multidimensional comprising inter-company coordination coopetition, coordination coopetition portfolios, learning coopetition, coopetition proactive and transformation coopetition. This sets the scene for further work to examine the interaction of the dimensions and effects of this interaction on the performance of coopetition. The third effect of the learning process coopetition, as the driver of the potential ability of coopetition and contingent factors relationship with performance.

In European countries, coopetition is not a new thing. Research linking coopetition biotechnology industry with the company's performance in Europe was made by Garcia C., A. and Velasco C.A.B, (2002). The purpose of this empirical study is to analyze the relationship between the different strategic-behavior with the performance of the industry that has some features that are typical of this. Biotechnology is representative of the high-tech industry where the product development process (from research to commercialization activities) take a long time, research intensive and protracted. The findings of this study is that the support for cooperation with a direct competitor to contribute positively and significantly to the product line. These results confirm the argument of the theoretical framework that saw coopetition as the right strategy. Also, cooperation with universities and research institutes that do not compete with large enterprises and diversification into biotechnology has a positive effect on the product line though at a lower level than the direct relationship with competitors.

In China, (Liu, et al, 2014) conducted a study on typology and the influence of coopetition between buyersupplier relationships on a sample of 225 Home Appliance Industry in China. This study uses an integrated approach to test the benefits of the relationship and transaction costs in buyer-supplier relationships. The findings that the buyer-supplier perform coopetition based on each degree of cooperation and competition. Every situation coopetition then correspond to a unique level of benefits the relationship and transaction costs. It is also stressed that the competition has a positive effect on transaction costs and negative effects on the benefits of the relationship, while stimulating greater cooperation benefits of their relationship but affect transaction costs especially at the low level of competition.

Research from M. Johansson (2012) on The Balancing Act-Cooperating with Competitors concluded that the balance coopetition simultaneously and from time to time is something that is challenging and requires a Managerial Capabilities of the company. This study explores the company's ability to balance the logic as opposed to interaction of time and found the experience necessary to develop coopetition in an ability to feel, see and adapt to the potential dilemma, to manage tensions and act on opportunities coopetition. This ability is important for companies to balance the duality of cooperation and competition interactions that vary in strength at the same time and from time to time. This research is useful for the company to investigate the behavior of role-playing company and the ability to manage conflict role. Also examined how the balance of the company through portfolio asymmetrical relationship. This is about coopetition advancing research in the context of SMEs. (Wassmer, 2010). This study shows how the role of flexibility and agility is an important measure of SME alliance portfolio management capabilities. Also explored the company's ability to balance temporality on coopetitive relations strategy, which supports to examine how companies manage time related dilemmas in coopetition (Yami et al, 2010 
;. Czakon, 2010). Full of ideas of temporality this study shows how the concept of coopetition more dynamic necessary to admit that the company can participate in many relationships coopetitive at the same time, each with a speed of change, direction and duration. Finally, this study provides new insights into how the ability to balance strategic dilemma in coopetition could have implications on innovation and the creation of business opportunities.

In the future the issue of coopetition is still an interesting trend to study as proposed by Dagnino, (2013) that coopetition studies are undergoing today the best of times in their almost two-decade history. In fact, taken apart Articles being published as a stand-alone original and review contributions in journals, a consistent stream of publications, especially special issues of international journals dedicated to coopetition (Industrial Marketing Management, International Studies of Management and Organization, International Journal of Technology Management), or to the interplay of competition and cooperation (Strategic Management Journal) is about to Appear in print in the next one and half years. This condition will certainly give another wave of huge boost to coopetition as a recognized areas of research and practice.

\section{Entrepreneur and coopetition role in achieving social well-being and Development}

As the world experiencing great challenges, for example the problem of population growth, lack of available jobs, moral and ethical challenges and many other problems that are related to one another. The global competition resulting in natural resources, human resources, science, technology, and Lifestyle should have the advantage, because these resources move freely without limit past the boundaries of the state and these advantages will make the resource will remain in the competition. Facing this challenge will require resources including qualified human resources that ensure efficiency and effectiveness.

All the prerequisites mentioned earlier is inside an entrepreneur is creative, innovative, competitive and cultured. Activities undertaken an entrepreneur has a socio-economic impact because it can create jobs, improve the quality of life, improve income distribution, use and mobilize resources to improve national productivity of a country. Esmara (1986) argued that development measuring element consists of three components: population and employment, economic growth, as well as equity and social well-being. Based on these ideas, the entrepreneur can promote development as an entrepreneur can provide jobs that improve people's well-being.

Todaro (2006) states that the source of economic progress may include a variety of factors, but in general it can be said that the main sources of economic growth is the investments that improve the quality of capital or human resources and physical, which subsequently managed to increase the quantity productive resources and can raise the productivity of all resources through new discoveries, innovation and role in advancing technology. Based on these opinions, it was concluded that the entrepreneur can affect a country's economic growth rate.

The role of the entrepreneur in creating innovative production processes and dare to bear the risk has an important role in boosting economic growth to further improve the well-being of the community. If the state had more number of entrepreneurs then the country will be more advanced and prosperous. An entrepreneur is always creating new innovations to create new opportunities in creating a product and provides jobs. To print the number entrepreneurs need strategic measures and policies. This is where the government can play a role by providing education and training to prospective entrepreneurs and makes it easy for the beginner who wants to be an entrepreneur.

With the positive impact of the entrepreneur, the job seekers were originally interested only in the formal sector is expected to change his views and switch on informal sectors. According to Stephen R. Covey (1989) the change is often a painful process. The process of change should be motivated by a higher purpose, by willingness to subordinating what you think you want now for what you want in the future.

Entrepreneur with coopetition strategy is needed in the present and future era. This is evidenced by the success of China entering the global market as the research results Zhan Alian (2012) with the findings that (a) .Intellectual Property Rights (IPR) has become an important part of China's technology policy and has been used as a tool to stimulate and enhance innovation; (b). Chinese multinational companies have graduates realize and see intellectual property rights as a necessary weapon or leverage on their way to the global market; and (c). Through innovative activities, by implementing learning by doing and strategy coopetition, pioneering firms will play an important role in the global competition. Serious challenges faced by the effort of innovation Information Communication Technology (ICT) in the China market remains to be seen, decisive and ambitious China will have a profound impact on the Chinese economy and the global and Chinese companies and multinationals in the global market. 
Panelists at the WTO Public Forum (2009): Global Problems, Global Solutions; Hisham El Sherif, (Chairman, Nile Capital, Cairo, Egypt). He is an Egyptian entrepreneur engaged in the technologies of the 21st century. He goes beyond his pure business responsibilities to improve regional and international governance. He is also deeply involved in the Evian Group Arab Region, an Arab regional coalition of prominent business, government and opinion leaders, aiming to ensure the greater competitiveness of the Arab region and Facilitate its integration in the global economy. El-Sherif challenged the audience with the main three points:

1. Are we doing well? Can we do better? He felt that the world today is worse politically, economically and socially than a few Decades ago. According to him, we are facing a huge divide in multiple domains (in the digital, political, economic and social sectors mainly); consequently, we need a strong sense of collaboration. $\mathrm{He}$, too, stressed the urgency of a paradigm shift.

2. Are the institutions we have created working? Are they working for the business community, the consumers, or for themselves? Do people in the streets feel the impact of Reviews their action? By 2030, 100 million jobs will need to be created in the Middle East region, which is equivalent to an investment amounting to US \$ 3 trillion. Furthermore, Hundreds of Thousands of schools and hospitals will need to be built, which amounts to another $\$$ 8 trillion.

3. What is needed to face the challenges the world we will be confronted with a few years from now?

a. Partnerships are the only way out, specific scripts called for the Middle East.

There is a need for all actors to be Involved: constituencies (workers and consumers), the business community and politicians.

b. Governance needs to be part and parcel of what is taught at school and put in practice locally, regionally and internationally from, whether at the business or in the state level.

c. Leadership: what does it mean to have a leader in his position of power for more than 40 years? What is his contribution for his society and fellow citizens? Nowadays, limiting the income of CEOs is being discussed. Why are the number of years spent in power not being challenged?

When observed the things uttered by Hisham that in addition to the need for the involvement of business actors and the need for governance and leadership problem, so it will need cooperation. Coopetition strategy is very suitable to be applied to address and answer these questions last global.

\section{CONCLUSION}

Based on the review of the literature which is reinforced by empirical evidence it can be concluded that:

- Entrepreneurs who use the strategy of coopetition have a very important role in improving the well-being of society and in promoting development including economic development.

- Businesses that implement coopetition strategies to increase performance.

- Improved performance for the company or other business unit is a sign of continuity of the business and ensuring business continuity. This means that the share of entrepreneurs in carrying out its role as a provider of goods and services for consumers can be sustainable.

\section{REFERENCES}

Akdogan A. Dogan N.O. and Cingoz A., 2015, Coopetition as a Business Strategy: Determining the Effective Partner Selection Criteria Using Fuzzy AHP, International Review of Management and Business Research Vol. 4 Issue.1.www.irmbrjournal.com

Ananta Et al. 2012, Coopetition In ASEAN, A study exploring the possibility of Coopetition in the Telecommunications Industry in ASEAN (ABS Learning Team Project)

Bengtsson, M.and Kock, S. (1999). Cooperation and competition in relationships between competitors in business networks. Journal of Business \& Industrial Marketing, 14, 178-193.

Bengtsson, M. and Kock, S. (2000) 'Co-opetition in business networks - to cooperate and Compete simultaneously', Industrial Marketing Management, Vol. 29, No. 5, 
pp.411-426.

Bielawska, A.Z. (2013); Coopetition as a factor in the development of innovative and technologically advanced firms: an example of the high-tech sector, ISBM International Symposium, Kitakyushu International Conference Center, Japan,3-5 April 2013

Brandenburger A. and Nalebuff B. (1996): Co-Opetition. Doubleday, New York.

Bygrave, W. D. 2004. The Portable MBA in Entrepreneurship: Third Edition/edited by William D. Bygrave, Andrew Zacharakis. - Ed. 3 - New Jersey : John Willey \& Sons Inc.

Covey, Steven R, 1989, Seven Habits of Highly Effective People: Powerful Lessons in Personal Change, New York: Simon and Schuster.

Dagnino G.B., 2013, Coopetition strategy in Theory and in Practice, University of Catania Italy, Mastin Kipp at Oprah's Super Soul Sunday, Jan 2013 Esmara, Hendra. 1986. Planning and

Development in Indonesia. Gramedia Pustaka Utama, Jakarta.

Garcia C, A. and Velasco C.A.B, 2002, Co-opetition And Performance ; Evidence from European Biotechnology Industry, Annual Conference Of Euram on : Innovate Research Management, Stockholm, Sweden, May 9-11, 2002

Gnyawali, D. R., He, J., and Madhavan, R. (2006). Impact of Co-opetition on Firm Competitive behavior: an empirical examination. Journal of Management, 32, 507-530.

Kossyva,D.Sarri K and Georgopoulos N., 2014, Co-Opetition : A Business Strategy For SMES In Times of Economics Crisis, South-Eastern Europe Journal of Economics 1 pp. 89-106

Leeson, P.T. and P.J. Boettke. 2009. Two-tiered entrepreneurship and economic development. International Review of Law and Economics, Elsevier, vol. 29(3), pages 252-259

Liu Y, Luo Y, Yang P, and Maksimov V, 2014, Typology and Effects of Co-opetition in Buyer-Supplier Relationships: Evidence from the Chinese Home Appliance Industry, Management and Organization Review 10:3, November 2014, pp 439-465

Mariani M,M and Kylänen M, 2013, Public and Private Dynamics and Co-opetition: Evidence from the Tourism sector, The Rimini Centre For Economic Analysis, Working Paper 14_13, Rimini (RN) - Italy,www.rcfea.org - secretary@ rcfea.org

Johansson M. 2012. The Balancing Act- Cooperating with Competitors, UMEA School of Business and Economics, Elektronisk version tillgänglig på http://umu.diva-portal.org/Tryck/Printed by: Print \& Media Umeå, Sweden

Ngo De, D., Okura, M. 2008. Coopetition in a mixed duoploy market, Eco Mod 2008 International Conference on Policy Modeling, Berlin, 2- 4 July 2008

Padula G. and Dagnino G.B. (2007): Understanding the Rise of Coopetition: The Intrusion of Competition in a Cooperative Game Structure. "International Studies of Management and Organization", Vol. 37, pp. 32-52.

Prasistyo, 2010, Memenangkan Persaingan melalui Value Creation, http://www.tsm.ac.id/MB/MB.2.2.September.2010/Coopetition-Strategi Memenangkan Persaingan melalui Value Creation.pdf

Schilke, O. \& Goerzen, A. 2010. Alliance Management Capability: An Investigation of The Construct and Its Measurement. Journal of Management, 36: 1192-1219.

Schumpeter J. (1934): The Theory of Economic Development. An Inquiry into Profits, Capital, Credit, Interest and the Business Cycle. Harvard University Press.

Sherif, H.E. 2009, Global Problems Global Solutions, WTO Forum Panelis, Swizerland Todaro M.P. 2006. Economic Development in the Third World, the Erlangga Publisher, Jakarta

Zhan A. 2012, Co-opetition in Pursuing Global markets: Evidences from China's ICT

Sector 2012 International Conference on Innovation and Information Management (ICIIM 2012) IPCSIT vol. 36(2012) (C) (2012) IACSIT Press, Singapore

Zimmerer, T.W. and Scarborough, N M. 1998, Essential of Entrepreneur and Small

Business Management 2th. Prentice Hall 
Prasistyo, 2010, Memenangkan Persaingan melalui Value Creation,

http://www.tsm.ac.id/MB/MB.2.2.September.2010/Coopetition-Strategi Memenangkan Persaingan melalui Value Creation.pdf 